Zeszyty Naukowe Szkoły Głównej Gospodarstwa Wiejskiego w Warszawie

Problemy Rolnictwa Światowego tom 19 (XXXIV), zeszyt 1, 2019: 79-87

DOI: 10.22630/PRS.2019.19.1.7

Piotr Kułyk $^{1}$, Piotr Dubicki ${ }^{2}$

Uniwersytet Zielonogórski

\title{
Uwarunkowania zachowań konsumentów na rynku żywności ekologicznej
}

\section{Determinants of Consumer Behavior on the Organic Food Market}

\begin{abstract}
Synopsis. Poznanie zmieniających się potrzeb konsumentów jest ważnym elementem budowania przewagi konkurencyjnej przedsiębiorstwa. Celem artykułu jest przedstawienie zachowań konsumentów na lokalnym rynku produktów ekologicznych. W artykule przedstawiono zagadnienia związane z rynkiem żywności ekologicznej. Zdefiniowano i scharakteryzowano pojęcie produktu ekologicznego, omówiono kontrolę i certyfikację produkcji ekologicznej oraz czynniki wpływające na jakość żywności i popyt na produkty ekologiczne. Przeprowadzono badanie ankietowe na rynku lokalnym mające na celu scharakteryzowanie uwarunkowań zachowań konsumentów na rynku żywności ekologicznej. Na podstawie przeprowadzonych badań ankietowych i analizy danych statystycznych można zauważyć, że współczesny konsument jest świadomy tego co kupuje. Jakość i skład produktu to najważniejsze czynniki, które wpływają na podejmowane przez nich decyzję. Konsumenci coraz częściej rezygnują z konsumpcji żywności tradycyjnej na korzyść produktów ekologicznych.
\end{abstract}

Słowa kluczowe: świadomość ekologiczna, żywność ekologiczna, zachowania konsumentów

\begin{abstract}
Understanding the changing needs of consumers is an important element of building a competitive advantage of the company. The aim of the article is to present consumer behavior on the local market of organic products. The article presents issues related to the organic food market. The concept of organic product was defined and characterized, control and certification of organic production as well as factors affecting food quality and demand for organic products were discussed. In addition, a survey was conducted on the local market to show the determinants of consumer behaviour on the organic food market. Based on the surveys carried out and the analysis of statistical data, it can be seen that the modern consumer is aware of what he is buying. The quality and composition of the product are the most important factors that influence the decision they make. Consumers are increasingly giving up the consumption of traditional food in favor of organic products.
\end{abstract}

Key words: the ecological awareness, organic food, consumer behaviour

JEL Classification: Q18, Q57, P36

\section{Wstęp}

Rozwój rynku żywności ekologicznej w ujęciu lokalnym i międzynarodowym nie przebiega w sposób równomierny. Natomiast rosnąca liczba konsumentów oraz ich większa

${ }^{1}$ dr hab. inż., prof., UZ, Katedra Ekonomii Międzynarodowej, Wydział Ekonomii i Zarządzania, Uniwersytet Zielonogórski, ul. Podgórna 50,65-246 Zielona Góra, e-mail: p.kulyk@wez.uz.zgora.pl; https://orcid.org/0000-0003-2786-4020

2 mgr, Katedra Ekonomii Międzynarodowej, Wydział Ekonomii i Zarządzania, Uniwersytet Zielonogórski, ul. Podgórna 50, 65-246 Zielona Góra, e-mail: p.dubicki@wez.uz.zgora.pl; https://orcid.org/0000-0002-7812-8966 
świadomość powodują wzrost wewnętrznego zróżnicowania tego rynku. Żywność ekologiczna, to przede wszystkim żywność certyfikowana, która jest produkowana w specjalny sposób. Ściśle określone przepisy i kontrolna nad procesem produkcji i dystrybucji mają zagwarantować wysoką jakość produktów. Zadowolenie nabywców oraz ich świadomy wybór wpływa na wzrost popytu na produkty ekologiczne Zachowania rynkowe konsumentów żywności są bardzo zróżnicowane, a ich preferencje ulegają zmianie pod wpływem różnorodnych czynników oraz poszerzenia oferty produktów ekologicznych. Przemiany jakie zachodzą w otoczeniu konsumentów w znaczący sposób wpływają na ich styl życia oraz postawy. Nowe warunki społeczne i ekonomiczne, które są następstwem procesu transformacji polskiej gospodarki wpłynęło w znaczącym stopniu na przeobrażenia zachowań podmiotów rynkowych, a w szczególności konsumentów. Celem artykułu jest przedstawienie zachowań konsumentów na lokalnym rynku produktów ekologicznych. Analizy ilościowe uzupełniono badaniami ankietowymi, co pozwoliło na stworzenie sylwetki konsumenta proekologicznego oraz zwrócenie uwagi na czynniki, które wpływają na decyzje konsumentów podejmowane na rynku żywności.

\section{Pojęcie produktu ekologicznego}

Żywność pochodząca z przetwórstwa i rolnictwa ekologicznego określana jest mianem ekologicznej, organicznej, biologicznej lub biodynamicznej. Takie rolnictwo zajmuje się zrównoważoną produkcją zwierzęcą oraz roślinna, co pozwala osiągać w obrębie gospodarstwa równowagę paszowo-nawozową. Tego typu rolnictwo oparte jest na środkach nieprzetworzonych. Istotne jest odrzucenie w procesie produkcji żywności środków chemii spożywczej, weterynaryjnej i rolnej, co umożliwia uzyskanie wysokiej jakości biologicznych płodów o parametrach zbliżonych do jakości żywności powstałej bez ingerencji człowieka, czyli w sposób naturalny. Trzeba mieć jednak na uwadze globalne zanieczyszczenie środowiska, co nie pozwala na zagwarantowanie, że jakakolwiek żywność jest wolna od zanieczyszczeń (Miśniakiewicz, Suwała, 2006).

Współczesny rynek żywności możemy według z jednej klasyfikacji podzielić na cztery subrynki: rynek żywności funkcjonalnej, rynek artykułów konwencjonalnych, rynek produktów wygodnej żywności oraz rynek żywności ekologicznej (Niedzielski, 2018). Wzrost konsumpcji produktów ekologicznych związany jest ze zwiększoną świadomością ekologiczną wśród społeczeństwa. Uwarunkowane jest to zainteresowaniem mediami tą problematyką, która może pomóc w podejmowaniu świadomych decyzji przez konsumentów oraz samą zmianą stylu życia. Istnienie coraz większej ilości substytutów produktów tradycyjnych, zmiany w podejściu konsumpcji w aspekcie ochrony i troski zarówno o społeczeństwo jak i środowisko wskazuja, że proekologiczne zachowania są coraz istotniejsze we współczesnym świecie (Wilk, 2010).

Wśród polskich konsumentów proekologicznych najbardziej widoczne zmiany zaszły na rynku produktów żywnościowych. Żywność konwencjonalna od ekologicznej różni się pod trzema względami (Zrałek, 2010):

1) ekologiczne artykuły spożywcze są pozbawione środków zapachowych, sztucznych barwników oraz konserwantów,

2) w gospodarstwach ekologicznych zwierzęta żywi się przede wszystkim paszami pochodzącymi $\mathrm{z}$ danego gospodarstwa ekologicznego. Dokupywanie paszy 
ekologicznej zawierającej niewielki udział paszy konwencjonalnej jest również dopuszczalny,

3) w produkcji ekologicznej nie są używane nawozy sztuczne oraz środki chemiczne.

Sprzedaż produktów ekologicznych stale wzrasta. Największy udział w rynku zdrowej żywności mają państwa zachodnioeuropejskie oraz skandynawskie. Zauważalny jest również trend, że do dynamicznego rozwoju ekologicznego rynku przyczyniają się również państwa Europy Środkowej. Na polskim rynku wyróżniamy takie kanały sprzedaży jak: sklepy specjalistyczne z asortymentem ekologicznym, specjalistyczne stoiska znajdujące się na targowiskach, okazjonalne kiermasze oraz zakup zdrowych produktów bezpośrednio u producenta (Żakowska-Biemans, 2011).

\section{Kontrola i certyfikacja produkcji ekologicznej}

Certyfikacja i kontrola wszystkich podmiotów gospodarczych wprowadzających na rynek żywność ekologiczną odbywa się na każdym odcinku łańcucha podaży. Funkcjonowanie tego systemu jest niezbędne aby być wiarygodnym w oczach konsumenta, który musi posiadać wiedzę czy produkty ekologiczne wprowadzane na rynek wyprodukowane zostały zgodnie $\mathrm{z}$ obowiązującymi przepisami. Podstawową rolą tego systemu jest monitorowanie procesu wytwarzania, a nie kontrola produktu.

Identyfikacja artykułów ekologicznych pośród żywności konwencjonalnej umożliwia prawidłowe oznakowanie, które informuje konsumentów, że proces wytwórczy danego produktu był kontrolowany. Każdy produkt ekologiczny na etykiecie musi posiadać następujące informacje (Jak rozpoznać...):

1) unijne logo żywności ekologicznej,

2) numer identyfikacyjny jednostki certyfikującej,

3) oznaczenie miejsce pochodzenia.

Zgodnie z rozporządzeniem Komisji Unii Europejskiej (nr 271/2010) z dnia 24 marca $2010 \mathrm{roku}^{3}$ ustanowiono zasady znakowania produktów ekologicznych. Od dnia 1 lipca 2010 wprowadzono obowiązek umieszczania na etykietach ekologicznych certyfikowanych produktów unijnego logotypu produkcji ekologicznej. Logo to można stosować tylko i wyłącznie, jeśli dany produkt został wytworzony zgodnie $\mathrm{z}$ wymogami zawartymi w unijnym rozporządzeniu. Logo produkcji ekologicznej tworzy 12 gwiazdek układających się w kształt liścia na zielonym tle. Jednak w wyjątkowych sytuacjach może być używany również symbol czarno-biały; jeśli zastosowanie wersji kolorowej jest niemożliwe.

W warunkach szerokiej dostępności produktów żywnościowych proces certyfikacji jest $\mathrm{z}$ jednej strony elementem wyróżnienia tych produktów, $\mathrm{z}$ drugiej zaś dostarcza bardziej precyzyjną informację dla konsumenta o jego właściwościach. Ponadto, jest także swoistą ochroną zapewniającą zwrot kosztów w wytwarzaniu tych produktów z uwagi na dłuży czas produkcji i wyższe koszty w stosunku do produktów konwencjonalnych. Jest to mechanizm trwałego wypromowania, w tym przypadku europejskiego, produktu ekologicznego.

\footnotetext{
${ }^{3}$ ROZPORZĄDZENIE KOMISJI (UE) NR 271/2010 z dnia 24 marca 2010 r. zmieniające rozporządzenie (WE) nr 889/2008 ustanawiające szczegółowe zasady wdrażania rozporządzenia Rady (WE) nr 834/2007 w odniesieniu do unijnego logo produkcji ekologicznej
} 


\section{Czynniki wpływające na jakość żywności ekologicznej}

Definicja jakości żywności nie jest jednoznacznie określona, ponieważ zagadnienie to jest bardzo złożone, a próby definiowania ulegały zmianom na przestrzeni lat. Początkowo była ona klasyfikowana przede wszystkim ze względu na swoją wartość energetyczna. $\mathrm{Z}$ upływem lat i rozwojem nauki zaczęto zastanawiać się nad parametrami mierzalnymi takimi jak zawartość substancji szkodliwych dla zdrowia, czy też wartościami odżywczymi (Kijowski, Sikora, 2003). Obecnie zauważa się wzrost zainteresowania podejściem holistycznym do zagadnień związanych ze zdrową żywnością, podejście takie pozwala na analizę nie tylko parametrów, które są bezpośrednio związane z samym procesem spożywczym, ale także wielu parametrów pośrednich (Hallman, 2014).

Jakość produktów ekologicznych jest uwarunkowana licznymi czynnikami, głównie związanymi z zastosowanymi metodami produkcji oraz czystości miejsca hodowli i uprawy. Ważnym czynnikiem wpływającym na przetwórstwo produktów ekologicznych jest mała ilość dodatków sztucznych takich jak: środki słodzące, zapachowe i barwiące, syntetyczne kwasy thuszczowe, oraz większa ilość zarówno minerałów jak i witamin (Iurkova, Jędrzejczak i in., 2017). Na jakość produktów ekologicznych wpływa wiele czynników. Pośród, których ogromne znaczenie mają czynniki abiotyczne. Gwarantem wysokiej jakości jest gleba, wody gruntowe i powierzchniowe, które spełniają określone parametry jakościowe. Na rysunku 1 zostały przedstawione czynniki, które mają kluczowy wpływ na jakość ekologicznych produktów oraz surowców.

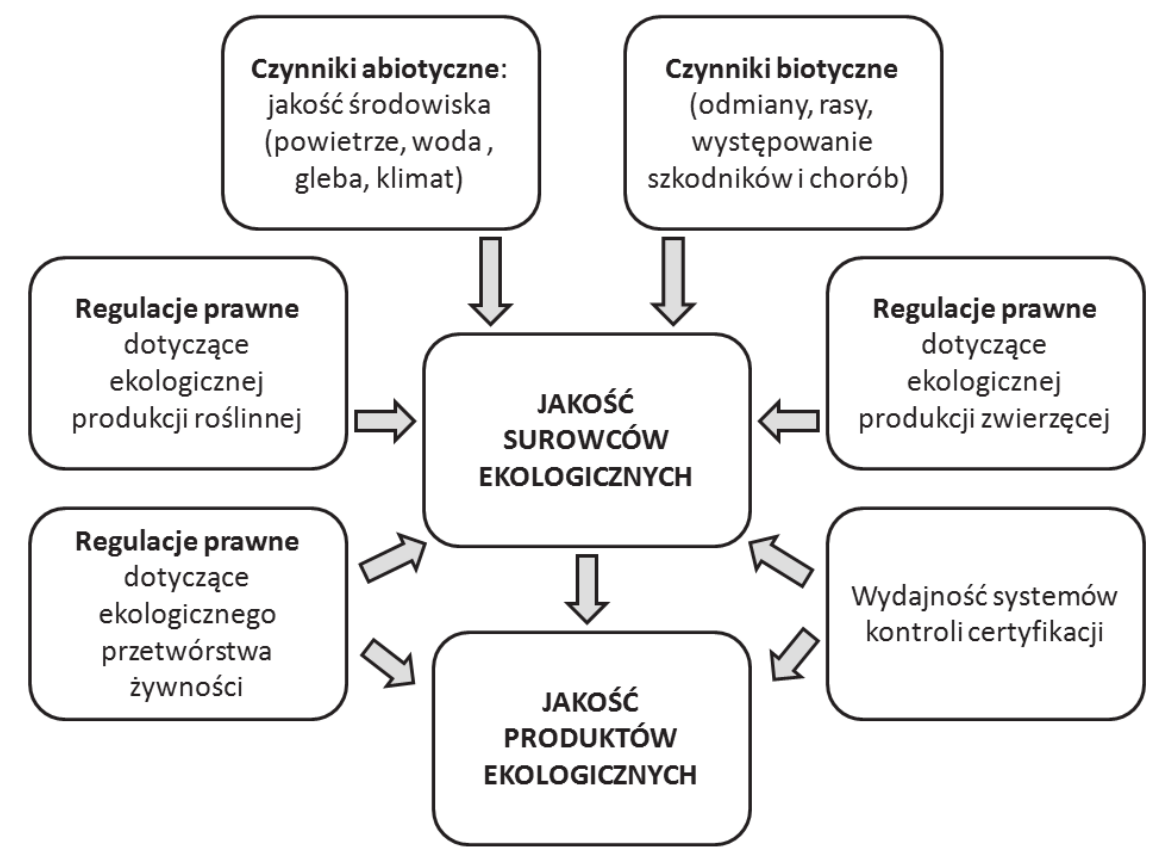

Rys. 1. Czynniki wpływające na jakość ekologicznych surowców i produktów

Fig. 1 Factors affecting the quality of organic raw materials and products

Źródło: Ewelina Hellman, Żywność ekologiczna. Wydawnictwo SGGW, Warszawa 2014, s. 8. 
Na jakość ekologicznych produktów żywnościowych wpływają regulacje prawne, które zawierają określone zalecenia i wytyczne obejmujące m.in. technologie przetwórstwa. Duże znaczenie ma również jakość surowców ekologicznych oraz wydajność systemów certyfikacji i kontroli, które są gwarantem zgodności procesu produkcji z wymaganiami. Do innych czynników można zaliczyć czynniki biotyczne (odmiany roślin, rasy zwierząt) oraz regulacje prawne, zawierające wytyczne co do produkcji zarówno zwierzęcej jak i roślinnej. Kształtują one całokształt warunków w jakich odbywa się produkcja i sprzedaż produktów ekologicznych.

\section{Metodologia i wyniki badań}

Badania zostały przeprowadzone metodą ankietowa, $\mathrm{z}$ wykorzystaniem kwestionariusza ankiety, a ich celem była ocena zachowań konsumentów na rynku żywności ekologicznej oraz określenie ich preferencji. W ewaluacji wzięto pod uwage częstotliwość kupowania zdrowej żywności, miejsce jej nabywania oraz określono kryteria, którymi kierują się konsumenci podczas zakupów żywnościowych. Badana populacja obejmowała 211 osób zróżnicowanych pod względem płci, wieku, wykształcenia oraz sytuacji materialnej. Badanie przeprowadzono w maju 2018 roku (dobór losowy przy 95\% poziomie ufności, obliczenia wykonane dla południowej części województwa lubuskiego). Pośród ankietowanych kobiety stanowiły większość (68\%), mężczyźni to 32\%. Ponad połowa badanych $(56 \%)$ to ludzie młodzi, którzy są pełnoletni i nie przekroczyli 25 roku życia, osoby w grupie wiekowej 26-35 lat stanowiły $32 \%$, kolejne $8 \%$ to osoby w wieku 36-50 lat. Najmniej liczną grupę stanowiły osoby po 50 roku życia $-4 \%$.

Większość respondentów $(66,4 \%)$ deklaruje, że kupują ekologiczną żywność nie rzadziej niż raz w miesiącu. Grupa konsumentów, która nigdy nie kupuje produktów ekologicznych stanowi 12,3\%. Badani konsumenci poproszeni o wskazanie cech kojarzących im się z żywnością ekologiczną przede wszystkim wskazali na zdrowie, aż $82,9 \%$ respondentów powiedziało, że to właśnie zdrowie jest główną cechą ekologicznej żywności. Na kolejnym miejscu znalazła się wysoka cena (64,9\%), którą trzeba zapłacić za certyfikowane produkty, co jednoznacznie pozycjonuje produkty ekologiczne w opinii konsumentów. 173 ankietowanych określiło swoją sytuację materialną jako dobrą i 30 jako bardzo dobra. Tylko $8 \mathrm{z}$ respondentów uznało, że ich sytuacja finansowa jest zła. Jednak wysoka cena nie odstrasza konsumentów, ponieważ 66,4\% kupuję żywność ekologiczną przynajmniej raz w miesiącu. Na kolejnym miejscu znalazła się wysoka jakość oferowanych produktów ekologicznych, na co zwróciło uwagę 93 badane osoby (44,1\%).

Mniej kojarzące się ze zdrową żywnością cechy to troska o środowisko, moda oraz trudna dostępność. Tylko 20,9\% ankietowanych uważa, że żywność ekologiczna jest trudno dostępna. Związane to jest ze wzrostem świadomości konsumentów i chęcią nabywania zdrowej żywności co przekłada się również na dostawców i sprzedawców proekologicznych produktów, którzy starają się zapewnić jak najłatwiejszy dostęp do certyfikowanych produktów. 


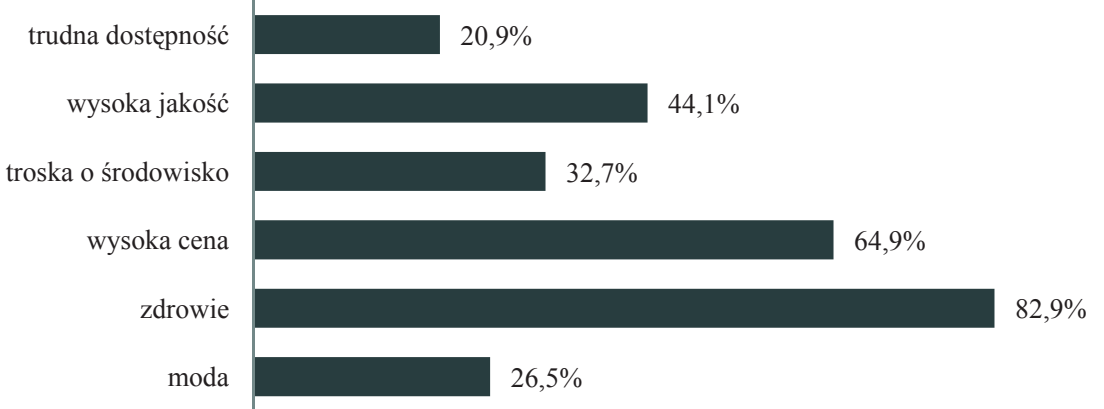

Rys.2. Cechy produktu kojarzące się z żywnością ekologiczną

Fig. 2. Product features associate with organic food

Źródło: badanie własne.

Najczęstszymi miejscami zakupu żywności ekologicznej przez badanych konsumentów są supermarkety. Ponad połowa $(53,6 \%)$ ankietowanych nabywa zdrową żywność w marketach. Spowodowane to jest łatwym dostępem do sklepów oraz mnogością produktów oferowanych w jednym miejscu. Wynika też ze zmiany podejścia samych marketów, które na stałe wprowadziły do swej oferty grupę produktów ekologicznych wyróżniając je systemie sprzedaży (często wydzielona półka, odpowiednio oznakowana) Kupowanie żywności ekologicznej na targowiskach deklaruje 34,4\% badanych. $25,4 \%$ nabywa ją w wyspecjalizowanych sklepach, gdzie na ogół mamy też lepszą dostępność do informacji o tych produktach. Pomimo rosnącej tendencji zakupów przez Internet konsumenci niechętnie nabywają produkty ekologiczne w sieci (zaledwie $11,5 \%$ respondentów).

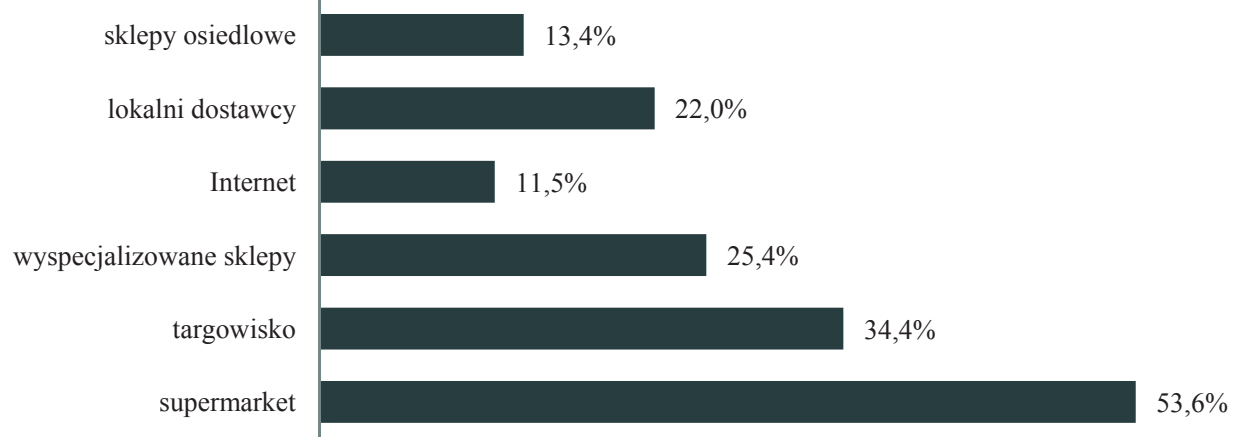

Rys. 3. Miejsca nabywania żywności ekologicznej

Fig. 3. Places to buy organic food

Źródło: badanie własne.

Respondenci wskazali również najistotniejsze cechy produktów na jakie zwracają uwagę podczas zakupu, co przedstawiono na rysunku 5 (skala ocen od 1 do 5 , gdzie 5 to najwyższa ocena). Za kluczową i najistotniejszą cechę produktów żywnościowych ankietowani uznali jakość produktu - 4,13 pkt. Kolejną pozycję zajmuje skład produktu 
(3,89 pkt.) Na trzecim miejscu respondenci wskazują cenę, przypisując jej 3,27 pkt. Pochodzenie produktu znalazło się na czwartym miejscu (3,08 pkt.). Najniżej oceniona została marka, do której konsumenci nie przywiązują dużej uwagi - 2,18 pkt.

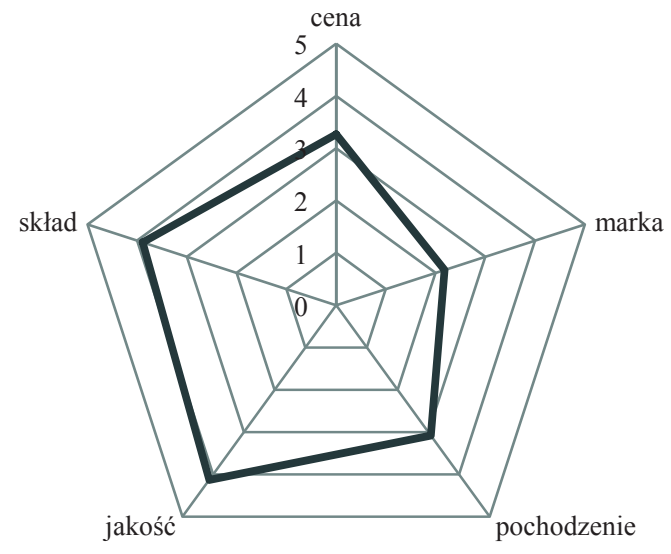

Rys. 4. Najistotniejsze cechy produktu

Fig. 4. The most important features of the product

Źródło: badanie własne.

Rynek żywności ekologicznej ma zróżnicowaną ofertę handlową, począwszy od produktów mięsnych, po produkty zbożowe, warzywa i owoce, aż po słodycze oraz inne produkty pochodzące z hodowli i upraw ekologicznych. Respondenci, którzy deklarują nabywanie zdrowej żywności poproszono o podanie grup żywnościowych produktów ekologicznych, które kupują (Rys. 5)

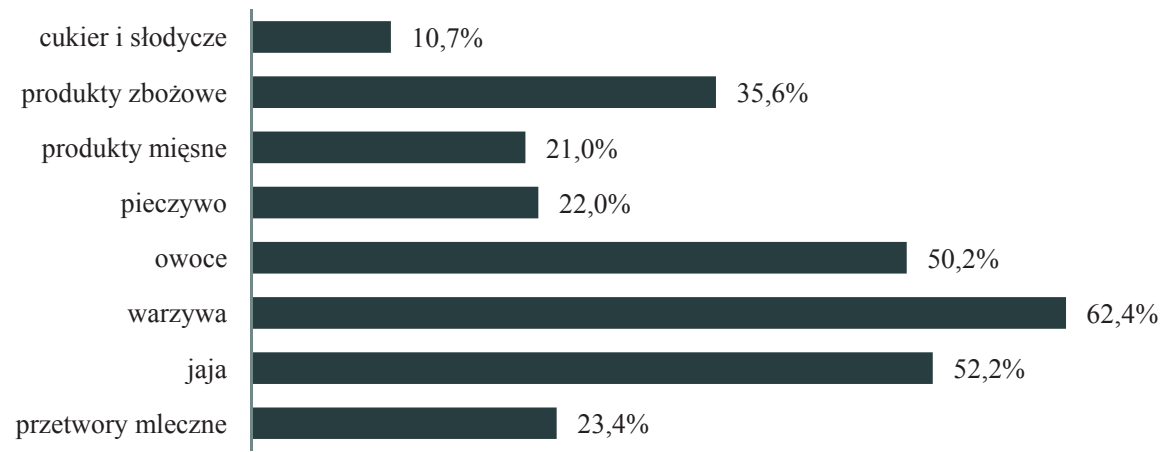

Rys. 5. Grupy nabywanych produktów ekologicznych

Fig. 5. Groups of organic products purchased

Źródło: badanie własne.

Najczęściej kupowane przez konsumentów produkty ekologiczne to warzywa $(62,4 \%)$. Na kolejnym miejscy znalazły się jaja oraz owoce. Czwarte miejsce zajmują produkty 
zbożowe $(35,6 \%)$. Przetwory mleczne pieczywo i produkty mięsne są bardzo zbliżone pod względem preferencji konsumentów co do zakupu. Najmniejszym powodzeniem cieszy się cukier i słodycze $-10,7 \%$.

\section{Podsumowanie}

Zainteresowanie konsumentów żywnością ekologiczną wpisuje się w nowe trendy postępowania na rynku żywności. Termin żywności ekologicznej obejmuje szeroką gamę produktów charakteryzujących się wysoką jakością, metodami produkcji oraz czystości miejsca uprawy i hodowli. Unijne regulacje prawne dotyczące ekologicznej żywności precyzują kryteria przyznawania znaków jakościowych oraz certyfikacji produktu i stanowią podstawę dla kształtowania korzyści ekonomicznych z produkcji żywności ekologicznej.

Produkty żywności ekologicznej kojarzone są ze zmianą stylu życia i ukierunkowaniem na zdrowie i aktywność. $Z$ drugiej strony jest ona postrzegana jako żywność droga. Te dwie cechy sprawiają iż jest ona adresowana do ograniczonej grupy konsumentów.

W ujęciu międzynarodowym utrzymuje się duże zróżnicowanie w segmencie rynku żywnościowego jakim są produkty ekologiczne. Dysproporcje te dotyczą zarówno udziału tej żywności w łącznej konsumpcji jak i jej struktury spożycia. Nie inaczej jest w ujęciu lokalnym. Z perspektywy rozważanego rynku lokalnego nastąiło wyraźne zwiększenie oferty i spożycia produktów, określanych mianem ekologicznych. Ich struktura jest, przynajmniej częściowo zdeterminowana lokalną strukturą produkcji, co wynika z zakupów od lokalnych dostawców bezpośrednio lub na targowisku. Rośnie natomiast znaczenie oferty od dużych producentów z uwagi na wzrost udziału zakupów w sieciach handlowych. Stanowi to poważne zagrożenie dla lokalnych struktur produkcji zorientowanych na ograniczone lokalizacyjnie rynki.

Na podstawie przeprowadzonych badań ankietowych i analizy danych statystycznych można zauważyć, że współczesny konsument jest świadomy tego co kupuje. Jakość i skład produktu to najważniejsze czynniki, które wpływają na podejmowane przez nich decyzję. Konsumenci coraz częściej rezygnują z konsumpcji żywności tradycyjnej na korzyść produktów ekologicznych.

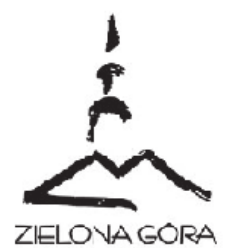

Zrealizowano przy pomocy finansowej Miasta Zielona Góra

This paper is co-financed by the city of Zielona Góra

\section{Literatura}

Hellmann, E. (2014) Żywność ekologiczna. Skrypt do ćwiczeń (Eco food. An exercise script). Wyd. SSGW, Warszawa.

Iurkova, M., Jędrzejczak, M., Stępień, N., Świstak, P., Musiałowska, P. (2017). Ekologiczność produktu jako ważny element jego jakości (Ecological nature of the product as an important element of its quality). Systemu Wspomagania w Inżynierii Produkcji, 6(1), 148-157 
Kijowski, S., Sikora, T. (2013). Zarządzanie jakością i bezpieczeństwem żywności (Food quality and safety management). WNT, Warszawa.

Miśniakiewicz, M., Suwała G. (2010). Żywność ekologiczna w świadomości Polaków (Organic food in the minds of Poles). Zeszyty Naukowe Akademii Ekonomicznej w Krakowie, 705, 57-75.

Niedzielski, J. (2018). Uwarunkowania rozwoju żywności ekologicznej (Conditions for the development of organic food). Roczniki Naukowe SERiA, 10(4), 279-283.

Rozporządzenie Komisji (UE) nr 271/2010 z dnia 24 marca 2010 r. zmieniające rozporządzenie (WE) nr 889/2008 ustanawiajace szczegółowe zasady wdrażania rozporządzenia Rady (WE) nr 834/2007 w odniesieniu do unijnego logo produkcji ekologicznej (Commission regulation (EU) No 271/2010 of 24 March 2010 amending Regulation (EC) No 889/2008 laying down detailed rules for the implementation of Council Regulation (EC) No 834/2007, as regards the organic production logo of the European Union). Pobrano z: https://eur-lex.europa.eu/legal-content/PL/ TXT/?uri=celex\%3A32010R0271.

Wilk, I. (2010). Konsument w koncepcji marketingu ekologicznego (A consumer in the concept of ecological marketing). ZN US Problemy Zarzq̨dzania, Finansów i Marketingu, 16, 59-68.

Zrałek, J. (2010). Czynniki motywujące konsumentów do zakupu ekologicznej żywności - wyniki badań bezpośrednich (Factors motivating consumers to buy organic food - results of direct research). ZN US Problemy Zarzqdzania, Finansów i Marketingu, 16, 391-400.

Żakowska-Biemas, S. (2011). Bariery zakupu żywności ekologicznej w kontekście rozwoju żywności ekologicznej (Barriers to the purchase of organic food in the context of organic food development). Journal of Research and Applications in Agricultural Engineering, 56(4), 216-220.

Jak rozpoznać żywność ekologiczną? (How to recognize organic food?). Pobrano 20 maja $2018 \mathrm{r}$. z: http://ekoexpo.pl/p1/zywnosc_ekologiczna.

Do cytowania / For citation:

Kułyk P., Dubicki P. (2019). Uwarunkowania zachowań konsumentów na rynku żywności ekologicznej. Problemy Rolnictwa Światowego, 19(1), 79-87; DOI: 10.22630/PRS.2019.19.1.7

Kułyk P., Dubicki P. (2019). Determinants of Consumer Behavior on the Organic Food Market (in Polish). Problems of World Agriculture, 19(1), 79-87; DOI: 10.22630/PRS.2019.19.1.7 